\title{
An Analyis of School Violence as Reflected in the Printed Media*
}

\author{
Zühal ÇUBUKÇU ${ }^{* *}$
}

\author{
Ayşe DÖNMEZ ${ }^{* * *}$
}

Received: 25 April 2013

Accepted: 14 Novamber 2013

ABSTRACT: School violence is one of the most important problems threatening physical and mental health of people in Turkey as well. The main purpose of this study is to analyze school violence as reflected in the print media between the years of 2005 and 2010. It aims to explore the dynamics of and reasons behind school violence. Besides, the context for school violence is also examined. In this study, national newspapers, namely Hürriyet, Cumhuriyet, Zaman and Sabah published between the years of 2005 and 2010 were scanned to detect news on school violence and detected news was content analyzed. Findings revealed that violence occurred mostly in primary schools between teachers and students. Also, news on school violence was mostly published in Hürriyet, but at least in Cumhuriyet.

Keywords: school violence, case study, teacher, student

\section{Extended Abstract}

Purpose and Significance: School violence is one of the most important problems threatening physical and mental health of people in Turkey as well. It is terribly increasing at a high speed. It is necessary to take this growing violence under control at proper time. Otherwise, it will go out of hands. Violence refers to immediate or chronic situations that result in injury to the psychological, social or physical well-being of individuals or groups. The level of children's exposure to community violence or media violence may vary. However, the psychological and behavioral risks that are associated with children's exposure to these types of violence are remarkably similar. The main purpose of this study is to analyze school violence as reflected in the print media between the years of 2005 and 2010. It aims to explore the dynamics of and reasons behind school violence. Besides, the context for school violence is also examined.

The following research questions were addressed based on those purposes:

1. What is the range of news on school violence according to years and newspapers?

2. What is the range of other news on violence according to years and newspapers?

3. What is the range of news in newspapers according to types of violence?

4. What is the range of news in newspapers according to by whom violence against whom occurs?

5. What is the range of news in newspapers according to formal education levels?

\footnotetext{
* Paper presented in the $20^{\text {th }}$ National Congress of Educational Sciences.

${ }^{* *}$ Sorumlu Yazar: Assoc. Prof., Eskişehir Osmangazi University, Eskişehir, zuhal_cubukcu@hotmail.com

${ }^{* * * *}$ Res. Assist., Eskişehir Osmangazi University, Eskişehir, aysedonmez@ogu.edu.tr
} 
Methods: In this study, national newspapers, namely Hürriyet, Cumhuriyet, Zaman and Sabah published between the years of 2005 and 2010 were scanned to detect news on school violence and detected news was content analyzed. Criterion sampling was employed to select newspapers. The Web archive of each newspaper was used to detect news based on incidence of school violence. As a result, 149 news on school violence was found.

Results: Findings revealed that news on school violence was mostly published in Hürriyet, but at least in Cumhuriyet. More than half of them were presented with no comment. Some news on school violence often makes readers think of schools as unsafe. The concept of violence is mostly perceived as physical violence. Physical violence is the mostly known violence type in the printed media while there is a little news on sexual violence because sexual issues are mostly seen as taboo issues in society. It is also found out that school violence occurs mostly between teachers and students. This is followed by school violence occurring between students and students. Students are mostly in the heart of school violence. Therefore, it is seen that students are both bullies and victims. Also, it was concluded that violence occurred mostly in primary schools between students and teachers.

Discussion and Conclusions: If school violence is being discussed in the news and media, this is a great opportunity to bring it up in the classroom. So, this can be a chance to speak about school violence in the classroom and teachers can warn and talk to students about what they should do if they are confronted with violence. Also, students can talk about their concerns about and fear of school violence. To prevent school violence, conflict resolution skills can be taught so that students can resolve their problems without committing violence. Violence prevention is such a too-broad topic and risk factors are so abundant that national media and public consciousness have already deconstructed it for their own purposes and understanding. This study is limited only with the printed media. Also, similar studies might be done on how visual media present news on school violence regarding accuracy and background of news, and whether there is a neglect or apathy in presentation of news. Thus, the whole picture can be drawn in terms of media. 


\title{
Yazılı Basına Yansımaları İle Okuldaki Şiddet Olaylarının İncelenmesi*
}

\author{
Zühal ÇUBUKÇU* ${ }^{* *}$
}

\author{
Ayşe DÖNMEZ $^{* * *}$
}

Makale Gönderme Tarihi: 25 Nisan 2013

Makale Kabul Tarihi: 14 Kasım 2013

\begin{abstract}
ÖZET: Bu çalışmanın amacı, okullarda meydana gelen şiddet olaylarını gazetelerde yer alan haberler aracılığıyla incelemektir. $\mathrm{Bu}$ araştırmada, okullarda meydana gelen şiddet olaylarının gazetelere nasıl ve ne sıklıkta yansıtıldığına, hangi tür olayların, hangi kademede ve kimler arasında yaşandığına ilişkin sorulara yanıt aranmaktadır. Bu kapsamda, 2005-2010 yılları arasında ulusal gazeteler (Hürriyet, Cumhuriyet, Zaman, Sabah) taranmış, okullardaki şiddet olaylarına ilişkin haberlerin analizinde betimsel analiz ve doküman incelemesi tekniği kullanılmıştır. Bu gazeteler "ölçüt örneklem" yöntemine göre amaçlı olarak seçilmiştir. Veriler, her dört gazeteye ilişkin arşivlerden alınmıştır. Haberleri seçerken şiddet olayının okul içerisinde gerçekleşmesi esas alınmıştır. Arşiv taraması sonucu dört gazetede 149 haber bulunmuştur. Okulda yaşanan şiddetle ilgili haberler en çok Hürriyet gazetesinde, en az ise Cumhuriyet gazetesinde yayınlanmıştır. Olayların en çok ilköğretim kurumlarında ve öğrenciöğretmen arasında yaşandığı sonucuna ulaşılmıştır.
\end{abstract}

Anahtar Sözcükler: okulda şiddet, örnek olay, öğretmen, öğrenci.

\section{Giriş}

İnsanın var olduğu her yerde şiddet de var olmuştur. İnsanın çevresini kontrol etme ve çevresine hükmetme isteği, insanlık tarihi boyunca şiddet, çatışma olaylarının ve savaşların yaşanmasına sebep olmuştur. Şiddet farklı şekillerde kendini göstermekte ve baskı, eziyet, korkutma, sindirme, öldürme, caydırma amaçlı davranışlar, toplumdan topluma farklılık göstermekle beraber, her toplumda sürekli yaşanmakta ve günlük yaşamın bir parçası olma özelliğini hâlen korumaktadır. Şiddet; insanın varoluşundan günümüze kadar uzanan süreçte çeşitli sorunların, çatışmaların sebebi ya da sonucu olarak gelişen bir sosyal durum, acı bir gerçektir. Şiddetin fiziksel, ruhsal ve duygusal olmak üzere içerik ve şekil olarak birbirinden farklı çeşitleri bulunmaktadır. Şekli ve niteliği farklı olsa da şiddetin birey üzerinde tahribat yarattığ üzerinde fikir birliğine varılmıştır. Dünya Sağlı Örgütü (DSÖ) tarafından şiddet; kişinin kendisine, bir başkasına ya da bir gruba karşı, yaralanma, ölüm, psikolojik zarar, gelişme geriliği ya da ihmal ile sonuçlanan (ya da sonuçlanma olasılığı yüksek olan) kasıtlı güç kullanımı ya da güç kullanma tehdidi olarak tanımlanmaktadır (World Health Organization, 1996). Şiddet, kelime anlamı olarak, insanın fiziksel ve ruhsal bütünlügüne yönelik her türlü maddi ve manevi olumsuzluğu dile getirmektedir. Bu olumsuzluğun temelinde ise dikkatimizi çeken iki kavramdan biri güç, diğeri ise saldırganlıktır. Şiddet eyleminde güç kullanımının yanı sıra saldırganlı̆̆ı yansıtan tüm söz, yaklaşım, tutum ve hareketler, bedensel ya da ruhsal etkilenmeler önemlidir. Şiddet, toplumun bütün gruplarını etkileyen karmaşık bir sorun olsa da daha fazla risk altında olan bazı gruplar tanımlanmıştır. Bu gruplardan biri, çocuklardır. Çocuklar şiddetin tanığı da, kurbanı da olabilirler. Çocukların birbirlerine şiddet uygulamaları okul ortamlarında sık görülen ve

\footnotetext{
${ }^{*}$ Bu çalışma, 20. Eğitim Bilimleri Kongresinde sözlü bildiri olarak sunulmuştur.

** Sorumlu Yazar: Doç. Dr., Eskişehir Osmangazi Üniversitesi, Eskişehir, zuhal_cubukcu@hotmail.com

**** Arş. Gör., Eskişehir Osmangazi Üniversitesi, Eskişehir, aysedonmez@ogu.ēu.tr
} 
önlem alınmazsa, ciddi fiziksel ve ruhsal incinmelere neden olabilecek bir sorundur. Çocukluk dönemi, yaşamın özel ve önemli bir dönemidir. $\mathrm{Bu}$ dönemde, bilişsel, duyuşsal ve davranışsal açıdan gelişimlerinin en önemli süreçlerini yaşayan çocukların dikkatle ve özenle korunmaları gerekmektedir.

Yaşamın her alanında olduğu gibi farklı şiddet türleriyle eğitim kurumlarında da karşılaşılmaktadır. Okullarda şiddet olgusu sadece ülkemize özgü bir durum değildir. Okullarda meydana gelen şiddet olaylarının diğer ülkelerde olduğu gibi ülkemizde de son yıllarda bir artış gösterdiği görülmektedir. Okullarda görülen şiddet olaylarının hem eğitim-öğretim etkinliklerini, hem de geniş bir çerçevede bireyin ruh sağ lığını olumsuz yönde etkileyeceği dikkate alındığında, konunun önemi açıkça ortaya çıkmaktadır (Terzi, 2007).

Okulda şiddet kavramı; gelişme ve öğrenmeyi engelleyen, okul atmosferine zarar veren suça yönelik eylemlere ve saldırganlığa işaret etmektedir (Furlong \& Morrison, 2000). Genel olarak okul bağlamındaki şiddet, öğrenci-öğrenci, öğrenciöğretmen ve öğretmen-okul yöneticileri/okul personeli arasında yaşanan tehdit ve fiziksel saldırıyı içermektedir. Okulda şiddet davranışları, fiziksel yaralama, psikolojik baskı ve mülke zarar verme gibi birçok kasıtlı davranışı kapsar. Bu olaylar, sıklık ve şiddet bakımından değişen davranışları da içerebilir. Bunlar; cinayet, silah kullanma, cinsel taciz, kavga, zorbalık, sözlü tehdit ve gözdağı verme, dayak, çete grupları, okul yolunda fiziksel veya sözle taciz şeklindedir (Astor, Benbenishty, Vinokur \& Zeira, 2006).

Okullarda saldırganlığın ve şiddetin görüntüsü, bir öğrencinin bir kişiye (öğrenci, öğretmen, yönetici gibi) küfür etmesinden, fiziksel zarar vererek sözlü tehditte bulunmasına, okul koridorunda iterek düşürmesine, kavga etmesine, silahla bir başka kişiyi tehdit etmesine, tecavüze teşebbüse/tecavüz etmesine, bıçakla yaralamasına veya öldürmesine ya da uyuşturucu/alkol alarak okula gelmesine kadar uzanan farklı biçimler alabilir (DiCanio, 1993; Goldstein, 1994).

Kramer, öğrenciler tarafından gerçekleştirilen şiddet veya suç davranışları arasında üçlü bir ayırım yapmaktadır: (1) Başkasının malına göz dikme şeklinde işlenen ekonomik suçlar ki bu şiddet biçimi, öğrencilerin maddi çıkar elde etmek için kullandıkları bir şiddet biçimidir. (2) Madde bağımlılığı endüstrisine dayalı suçlar ki bu şiddet biçimi, şiddet davranışlarını sergileyen çetelerin, üstünlük kurma mücadelesini içermektedir. (3) Güçsüz olma durumuyla ilişkisel şiddet ki bu şiddet biçimi ise, güçsüz pozisyonda olan bazı gençlerin küçük düşürülmeleri ile ilişkili olarak gerçekleşen bir şiddettir (Henry, 2000).

Medya ise şiddetin kaynakları açısından önemli bir yere sahip olan ve her geçen gün etkisi artarak devam eden bir faktördür. Yapılan çeşitli çalışmalar bu etkiyi ortaya koymaktadır. Altun-Akbaba, Güneri ve Baker (2006b) yaptıkları çalışmada, ilköğretim ikinci kademedeki öğrencilerin şiddete yönelik davranışlarının nedenleri arasında son yıllarda yaygınlaşan cep telefonları, sohbet odalarıgibi bilgi ve iletişim teknolojilerinin rolünün yer aldığı, öğrencilerin birbirlerine gönderdikleri mesajlarla şiddet kıvılcımının atıldığı ve böylece şiddetin ders aralarında veya dışarıda devam ettiği bulunmuştur. Hall 
(1999)'a göre, medya olanı biteni basitçe bize anlatmaktan öte, bir hammadde olan olay1, bir ürün olan habere dönüştüren, bu dönüştürmeyi yaparken de neyin haber değeri taşıdığına karar veren gizli mekanizmalar, ideolojik ve mesleki kodlarla davranan kurumsal bir ajandir.

\section{Medya ve Şiddet}

Medya, kitle iletişiminin yer aldı̆̆ı her türlü ortamı ve bu iletişim sırasında kullanılan her türlü aracı kapsar. Radyo, televizyon, VCD, disket, video, sinema, fotoğraf gibi görüntülü ve basılı tüm yayınlar medya olarak tanımlanmakta ve kitle iletişiminde rol almaktadır. Medya, anlama ölçümüzü ve eylemlerimizi biçimlendiren önemli bir iletişim ve toplumsallaşma aracıdır (Ayrancı, Köşgeroğlu, \& Günay, 2004). Kitle iletişim araçları, toplumda etki, denetim ve yeniliklerin potansiyel araçları olarak güç kaynağı, çoğu toplumsal kurumun çalışması için gerekli bilgilerin kaynağı ve aktarım aracıdır (McQuail \& Windahl, 1997). Medya, kitap, gazete, dergi, bilgisayar, televizyon, İnternet, video oyunları, müzik, film, CD-ROM, DVD, çağrı cihazları, cep telefonları, bilbordlar olarak tanımlanabilir ve bilgiyi aktarabilen basılı, elektronik ve dijital her araç bu tanıma dâhil edilebilir (Kartal \& Kıncal, 2009). Toplumun bilgilenmesinde güçlü bir araç olan basın yayın organları, bir yandan bilgilendirirken diğer yandan da bize bir dünya ve bu dünyaya ait imgeler ve görüntüler sunar. Bir anlamda dünyayı nasıl algılayacağımızı söyleyerek bizi yönlendirir, belli tutum ve davranış örüntülerinin yerleşiminde önemli rol oynar ve bazen de tek başına belirleyici olabilir (Palabıyıkoğlu, 1997).

Kitle iletişim araçları, toplumsal hayatımızın temel unsurlarından biri olmuştur. Kitle iletişimini yalnızca haber ve mesaj değişimi olarak değil; aynı zamanda düşünce, olgu ve veri iletim ve değişiminin tamamını içine alan bir unsur olarak değerlendiren Birleşmiş Milletler Eğitim, Bilim ve Kültür Örgütü (UNESCO), hazırladığı "İletişim ve Toplum" raporunda kitle iletişiminin işlevlerini şöyle sıralamaktadır:

- Haber ve bilgi sağlama: Kitle iletişim araçları, bireysel, toplumsal, ulusal ve uluslararası konuları akılcı bir biçimde kavramak ve gerekli kararları alabilmek için haber ve bilgi aktarırlar.

- Toplumsallaştırma: Kitle iletişim araçları, insanların toplum içinde varlıklarını sürdürebilmeleri için gerekli olan toplumsallaşmanın sağlanmasına yardımcı olurlar. Toplumun maddi ve manevi temelleri kitle iletişim araçları vasıtasıyla topluluk üyelerine aktarılır, toplumun maddi ve manevi temellerinin öğrenilmesi sağlanır.

- Motivasyon: Kitle iletişim araçları, toplumun amaçlarına ulaşmasında özendirici bir rol oynarlar. Bireyin toplum yaşamına olduğu gibi, bu amaçların gerçekleşmesine de katkıda bulunmasını sağlama işlevi görürler.

- Tartışma ve diyalog: Kitle iletişim araçları, tartışma ortamı oluşturarak kamusal çıkar konusunda var olan sorunların açığa çıkmasına yardımcı oldukları gibi diyalog yoluyla uzlaşma sağlanmasına da katkıda bulunurlar. Kitle iletişim araçları yoluyla ulusal ve uluslararası sorunlarda tartışma 
ortamına toplumun tüm kesimlerinin katılması sağlanarak, en uygun çözümün bulunması sağlanır.

- Eğitim işlevi: Kitle iletişim araçları, haber ve bilgi aktarırken, dolaylı olarak da toplumun eğitim seviyesinin yükselmesine yardımcı olurlar. Kitle iletişim araçları ayrıca bireylerin yetenek ve beceri düzeylerinin gelişmesinde de önemli rol oynarlar.

- Kültürel gelişme işlevi: Kitle iletişim araçları, sanatsal yapıtları yayarak kültürün gelişmesine katkıda bulunduğu gibi geçmişin mirasını korumada da önemli bir rol üstlenmektedirler.

- Eğlendirme işlevi: Kitle iletişim araçları, bireylere eğitim ve kültürün yanı sıra eğlence imkânı da sunmaktadırlar. Bireyler, kitle iletişim araçları vasıtasıyla hoşça vakit geçirebilmektedirler.

- Bütünleştirme işlevi: Kitle iletişim araçları, bir toplumdaki bireylerin birbirlerinin koşullarını tanımalarına yardımcı olduğu gibi farklı toplumların da birbirlerine yakınlaşmalarında önemli bir rol üstlenmektedirler. Kitle iletişim araçları, farklılıklar içinde birlikte yaşamak ve çoğulculuk ilkesine de katkıda bulunmaktadırlar (Aktaran: Özkan, 2006).

Eğitim ve medyanın içerik ve işlevleri incelendiğinde, örtüşen ve benzeyen içerik ve işlevlerinin bulunduğu belirlenebilir. Eğitim, genelde istendik ve kasitlı davranış değiştirme süreci olarak tanımlanır. Ancak eğitim, salt davranış değiştirme olarak tanımlanamaz. Eğitim, çok boyutlu işlevleri bulunan toplumsal bir kurumdur. Basın da salt haber ve yorum dağıtan bir kitle iletişim aracı olarak tanımlanamaz. Medya, sözcük anlamı ve kökü itibariyle kitleleri birbiriyle ilişki kurduran ve bağlayan anlamına gelir. Kitlelerin sosyalleşmesini sağlayan, davranış ve tutumlarının oluşmasında etkili bir toplumsal kurum olarak görülmektedir (Macionis, 1997, aktaran Erk1lıç, 2008).

Medya, dünyada olan olayları, haberleri insanlara duyurması, aydınlatması, gerçekleri göstermesi, toplumu bilgilendirmesi açısından inkâr edilemeyecek güçte bir araçtır. Ancak basın yayın organlarının, bir taraftan halkı aydınlatırken bir taraftan da şiddet gibi olumsuz mesajları da beraberinde verdiği için, özellikle son yıllarda şiddet konusunda eleştiri aldıkları gözlenmektedir. Medyada şiddet ögesinin varlığı, çocuk, yetişkin programı ayırımı gözetmemektedir. Çizgi filmler, haber programları, televizyon dizileri, komedi programları, sinema filmleri şiddetin yer aldı̆̆ 1 programlara örnek olarak verilebilir (Uysal, 2006). Günümüzde çocuklara ait televizyon programları, özellikle çizgi filmler, diğer programlara göre beş kat daha fazla şiddet içermektedir (Karatay \& Tokur Kesgin, 2006).

Televizyonun en büyük tüketici kitlesi çocuklardır. TV'ler en yıkıcı etkisini, etkiye en fazla açık durumdaki çocuklar ve gençler üzerinde göstermekte; bu etki, onların davranışlarına, sözlerine ve oyunlarına yansımaktadır. Günümüzde çocuklar, günlük yaşamları içerisinde çok uzun süre TV'ye bağlı kalmaktadırlar. Onlar en iyimser 
olasılıkla, 3-13 yaşları arasında günde ortalama 1-2 saat TV izlemektedirler (Ayranc1, Köşgeroğlu, \& Günay, 2004).

Çocuk ve gençlerin yaşamlarını anlamlandıracak, sorumluluk almalarını sağlayacak alanların oluşturulmasına ilişkin politikaların olmaması, çocuk ve gençlerin kendilerine ulaşan her iletiye karşı savunmasız hâle gelmesine yol açmaktadır (Gümüşoğlu, 2006). Şiddet, psikolojik, sosyo-kültürel ve sosyo-ekonomik boyutları ile kitle iletişim araçlarında ve özellikle TV'de yer alırken; bireysel/toplumsal, yasal/yasal olmayan ya da fiziksel/sözel/ruhsal yönlerden toplumsal yaşama yansımakta ve toplumsal yaşamı etkilemektedir (Ayrancı, Köşgeroğlu, \& Günay, 2004). Gürel (2006)'ya göre ise ister sinema filmi olsun, ister televizyon filmi, isterse çizgi film olsun, bilgisayar oyunları, muhtevaları itibariyle çocuğu içine doğduğu kültüre yabancılaştırmamalı, aksine o kültürle bütünleştirmelidir.

Palabıyıkoğlu (1997)’ye göre, toplumdaki insanlar ilgileriyle, tercihleriyle kitle iletişim araçlarını yönlendirme gücüne sahiptir. Bu açıdan öncelikle toplumun şiddete karşı duyarlılık kazanması gerekir. Okul ve şiddet ilişkisi üzerinde fikir ileri süren çok sayıda insanın, son dönemlerde şiddet olaylarının artışından, kitle iletim araçlarındaki şiddet içerikli program, dizi veya filmleri sorumlu tuttukları bilinmektedir. $\mathrm{Bu}$ çerçevede çok sayıda yönetici, öğretmen ve öğrencinin okullardaki şiddet olaylarının nedenlerine ilişkin çocukların özellikle izledikleri filmlerin kahramanlarına öykündükleri ve okulda akran grupları içerisinde söz konusu bu kahramana/kahramanlara özgü bir tavır ve dil geliştirdiklerini yaygın olarak belirtmişlerdir (Kızmaz, 2006).

Alan yazında medya ve şiddet ilişkisinin çalışıldığ diğer bir boyut ise, medyanın kamuoyu oluşturma konusundaki tartışılmaz etkisinden yola çıkılarak suç ve şiddet gibi duyarlılık gerektiren haberlerin nasıl verilmesi gerektiğine ilişkindir çünkü medyanın haberleri sunma şekli, insanların belirli konulara ilgilerini çekerek duyarlılıklarını artırmakta ve çeşitli kavramlara yönelik yargılar oluşturmasında etkin rol oynamaktadır (Menifield, Rose, Homa, \& Cunningham, 2001). İlgili alan yazında, şiddet ve sıklığına ilişkin basına yansıtılan haberler ile bilimsel çalışma bulguları arasında belirgin farklar olduğuna yönelik tartışmalar bulunmaktadır çünkü Rodgers ve Thorson (2001)'in de belirttiği gibi bazı şiddet olayları yaygın olmalarına karşın basında fazla yer almazken, yaygın olmayan bazı şiddet olayları satış ya da izlenme oranını artıracağı yönündeki beklentiler ile medyada sıkça yer bulmaktadır. Medyada şiddet olaylarının bu şekildeki sansasyonel sunumu ise, şiddet ve şiddet ile ilgili değişkenlere ilişkin insanlarda yanlış yargılar ya da görüşler oluşmasına neden olabilmektedir. İnsanların şiddete ilişkin oluşturdukları bakış açısı veya şiddete yükledikleri anlam üzerinde etkisi yadsınamayacak kadar büyük olan basının şiddet haberlerini sunma şeklinin ve bu haberlerin toplum üzerindeki etkisinin incelenmesi, şiddeti önleme ve sağaltım çalışmalarının başarısı açısından son derece önemlidir. Bu nedenle, çağımızda sisteme dönüt veren, bilgi sağlayan, kamuoyu oluşturan önemli araçlardan biri olarak değerlendirilen yazılı basında okulda şiddet olaylarının nasıl aktarıldığı, halkın bu 
konuda nasıl bilgilendirildiğinin incelendiği medya analizleri, şiddet ve şiddetin önlenmesi konusuna eğilen her disiplin için önem taşımaktadır (Toprakçı, 2001).

Medyanın önemli araçlarından biri de yazılı basın araçlarıdır. Yazılı basın denildiğinde ilk akla gelen gazeteler olmaktadır. Gazeteler, uygar toplumların önemsediği, yerel ve küresel olaylar hakkında bilgilendiği bir araçtır. Gazetelerin şiddet olaylarını, özellikle de okullardaki şiddet olaylarını nasıl yansıttıkları ise araştırılması gereken bir konudur. Okullarda yaşanan şiddet olaylarının dinamiklerinin anlaşılması, şiddetin hangi zaman diliminde, hangi ortamlarda, hangi nedenlerle ve hangi koşullarda ortaya çıktığının belirlenmesi bu araştırmanın gerekçesini oluşturmaktadır.

\section{Araştırmanın Amacı}

$\mathrm{Bu}$ araştırmanın temel amacı, Türkiye'de okullarda yaşanan şiddet olgusunu, 2005-2010 yılları arasında yazılı basına yansıyan olgular bağlamında incelemektir. Bu amaca yönelik aşağıdaki sorulara cevap aranmıştır.

1. Okullarda yaşanan şiddet olaylarının yıllara ve gazetelere göre dağılımı nasildir?

2. Diğer şiddet haberlerinin yıllara ve gazetelere göre dağılımı nasıldır?

3. Gazetelerde yer alan haberlerin şiddet türlerine göre dağılımı nasıldır?

4. Gazetelerde yer alan haberlerin, şiddet olaylarının kimler arasında yaşandığına göre dağılımı nasıldır?

5. Gazetelerde yer alan haberlerin örgün eğitim kademelerine göre dağılımı nasıldır?

\section{Yöntem}

\section{Model}

$\mathrm{Bu}$ araştırma nitel araştırma yaklaşımı benimsenerek gerçekleştirilmiştir. Araştırmada durum çalışması deseni kullanılmıştır. Durum çalışmasında bir duruma ilişkin etmenler (ortam, bireyler, olaylar, süreçler, vb.) bütüncül bir yaklaşımla araştırılır ve ilgili durumu nasıl etkiledikleri ve ilgili durumdan nasıl etkilendikleri üzerine odaklanılır (Yıldırım \& Şimşek, 2008).

\section{Çalışma Grubu}

$\mathrm{Bu}$ araştırmanın evrenini yazılı basın oluşturmaktadır. Yazılı basını, haberleri daha ayrıntılı, Türkiye'de yayınlanan tüm günlük gazetelerin oluşturduğu söylenebilir. Yazılı basın, haberleri daha ayrıntılı, derinliğine inerek sunması, belge niteliği taşıması ve istendiği zaman tekrar okunma, gözden geçirilme olanağı sağlaması nedeniyle seçilmiştir. Araştırmanın çalışma grubunu, Hürriyet, Cumhuriyet, Sabah ve Zaman gazetelerindeki 2005-2010 yılları arasında yer alan haberler oluşturmaktadır. Bu gazeteler "ölçüt örneklem" yöntemine göre amaçlı olarak seçilmiştir. Bu örneklem yöntemindeki temel anlayış, önceden belirlenmiş bir dizi ölçütü karş1layan bütün durumların çalışılmasıdır. Burada sözü edilen ölçüt veya ölçütler araştırmacı tarafından 
oluşturulabilir ya da daha önceden hazırlanmış bir ölçüt listesi kullanılabilir (Yıldırım \& Şimşek, 2008). Sözü edilen gazetelerin seçiminde; ulusal ölçekte yayın yapma, referans gazeteleri olma, farklı yayın gruplarına ait gazeteler olma gibi ölçütler dikkate alınmıştır.

\section{Verilerin Toplanması}

$\mathrm{Bu}$ araştırmada kullanılan veriler, doküman incelemesi yoluyla toplanmıştır. $\mathrm{Bu}$ kapsamda, veriler, 1 Ocak 2005-31 Aralık 2010 tarihleri arasında Hürriyet, Cumhuriyet, Sabah ve Zaman gazetelerinde okullarda şiddete yönelik yer alan haberlerin taranması sonucu elde edilmiştir. Veriler, her dört gazetenin İnternet sitesinden alınmıştır. Patton (2002) nitel araştırmalarda verilerin derinlemesine görüşmeler, doğrudan gözlem ve dokümanlar yoluyla elde edileceğini belirtmektedir. Berg (2007) de gazeteleri kamu arşivi olarak görmekte ve nitel araştırmalarda doküman olarak kullanıldığını belirtmektedir.

\section{Verilerin Analizi}

Okullarda yaşanan şiddet olaylarının basına nasıl yansıtıldığının araştırıldığı bu çalışmada, verilerin analizinde betimsel analiz ve doküman incelemesi tekniği kullanılmıştır. Doküman incelemesi, araştırılması hedeflenen olgu veya olgular hakkında bilgi içeren yazılı materyallerin analizini kapsar (Yıldırım \& Şimşek, 2008). Hürriyet, Cumhuriyet, Sabah ve Zaman gazetelerinde yer alan ve öznesi okullardaki şiddet olan haberler, bu araştırmanın verilerini oluşturmuştur. Ancak haberler seçilirken şiddet olayının okul içerisinde gerçekleşmesi esas alınmıştır. Nitel verilerin sayısallaştırılmasında sıklıktan yararlanılmıştır. Haberlerin içeriği, verilerin değerlendirilmesi ve bulguların yorumlanması aşamasında araştırmaya yön vermiştir.

\section{Bulgular ve Yorum}

Araştırma kapsamına alınan gazetelerde yer alan haberler analiz edilerek bulgular oluşturulmuştur. İlk olarak Tablo 1'de okullarda yaşanan şiddet olaylarının yıllara ve gazetelere göre dă̆ılımı verilmiştir.

Tablo 1

Okullarda Yaşanan Şiddet Olaylarının Yıllara ve Gazetelere Göre Dağılımı

\begin{tabular}{lccccccc}
\hline Gazete Ad1 & 2005 & 2006 & 2007 & 2008 & 2009 & 2010 & Toplam \\
\hline Hürriyet & 14 & 24 & 8 & 15 & 14 & 5 & 80 \\
Zaman & 3 & 10 & 5 & 5 & 3 & 8 & 34 \\
Sabah & 2 & 6 & 2 & 2 & 3 & 4 & 19 \\
Cumhuriyet & 2 & 5 & 2 & 1 & 4 & 2 & 16 \\
Toplam & 21 & 45 & 17 & 23 & 24 & 19 & 149 \\
\hline
\end{tabular}

Tablo 1 incelendiğinde 2005-2010 yılları arasında okulda yaşanan şiddet olayları ile ilgili Hürriyet gazetesinde 80 haber, Zaman gazetesinde 34 haber, Sabah gazetesinde 19 haber, Cumhuriyet gazetesinde ise 16 haber olmak üzere toplam 149 haber 
yayınlanmıştır. İncelenen gazeteler arasında en çok Hürriyet gazetesinde okulda şiddetle ilgili haber yayınlandığı, yıllara göre haberlerin dağılımına bakıldığında ise incelenen dört gazetede de en çok 2006 yılında haber yayınlandığı görülmektedir.

Ülkemizde 2006 yılının ilk beş ayında okullarda çıkan olaylarda; 14 öğrencinin öldürüldüğü, 104 öğrenci ile üç öğretmenin de yaralandığı bilgisi kitle iletişim araçlarında yer almıştır (Günday, 2006). Gazete arşivleri taranırken okullarda yaşanan şiddet olaylarının yanında okulda yaşanan şiddet olayları ile ilgili raporlar, seminerler, rehberler gibi haberlerin de yer aldığ 1 görülmüştür. Bu haberler diğer şiddet haberleri olarak ele alınmıştır. Tablo 2'de ise diğer şiddet haberlerinin yıllara ve gazetelere göre dağılımı verilmiştir.

Tablo 2

Diğer Şiddet Haberlerinin Yıllara ve Gazetelere Göre Dağılımı

\begin{tabular}{lccccccc}
\hline Gazete Ad1 & 2005 & 2006 & 2007 & 2008 & 2009 & 2010 & Toplam \\
\hline Hürriyet & 8 & 39 & 32 & 16 & 11 & 20 & 126 \\
Zaman & 10 & 116 & 41 & 32 & 24 & 21 & 244 \\
Sabah & 9 & 29 & 12 & 5 & 18 & 17 & 90 \\
Cumhuriyet & 8 & 40 & 10 & 9 & 38 & 26 & 131 \\
Toplam & 35 & 224 & 95 & 62 & 91 & 84 & 591 \\
\hline
\end{tabular}

Tablo 2'de verilen diğer şiddet haberlerinin gazetelere göre dağılımı incelendiğinde; diğer şiddet haberleri 244 haber ile en çok Zaman gazetesinde, en az 90 haber ile Sabah gazetesinde yayınlanmıştır. Cumhuriyet gazetesinde 131, Hürriyet gazetesinde 126 haber yayınlanmıştır. Yıllara göre dağılım incelendiğinde ise diğer şiddet haberleri, okulda yaşanan şiddet haberleriyle paralel olarak dört gazetede de en çok 2006 yılında yayınlanmıştır. Diğer şiddet haberleri ile ilgili olarak 02.10.2007 Zaman gazetesinde yayınlanan haberde "Okul önlerindeki şiddet masaya yatırıldı" başl1klı yazıda "XXXX Emniyet Müdürlüğ̈̈ tarafindan okul önlerindeki şiddet olaylarının önlenmesi için alınan güvenlik önlemleri, okul müdürleriyle masaya yatırıldı" olarak yer verilmiştir. 05.08.2010 tarihinde ise Zaman gazetesinde yayınlanan haberde Milli Eğitim Bakanı’nın açıklamalarına yer verilmiştir. "Milli Eğitim Bakanı, eğitim ve ögretime devam eden çocuklar arasında meydana gelen şiddet olaylarının azaldığını bildirdi. Milli Ĕ̈itim Bakanı'nın verdiği bilgiye göre 2006-07 döneminde 3 bin 14 olan vaka sayısı bu yılın ilk döneminde 356'ya geriledi." Tablo 3'te incelenen dört gazetede yer alan haberlerin sunum biçimleri ele alınmıştır. 
Tablo 3

Gazetelerde Yer Alan Haberlerin Sunum Biçimi

\begin{tabular}{lccccc}
\hline Sunum Biçimi & Hürriyet & Zaman & Sabah & Cumhuriyet & Toplam \\
\hline Yorumsuz & 45 & 22 & 10 & 10 & 87 \\
İddia & 23 & 8 & 7 & 5 & 43 \\
Kınayıc1 & 12 & 4 & 2 & 1 & 19 \\
Toplam & 80 & 34 & 19 & 16 & 149 \\
\hline
\end{tabular}

Tablo 3 incelendiğinde 87 gazete haberinin yorumsuz, 43 gazete haberinin iddia olarak, 19 gazete haberinin ise kınayıcı bir üslupla sunulduğu görülmektedir. Gazeteler incelendiğinde dört gazetenin de haberleri daha çok yorumsuz olarak sunmayı tercih etmesi dikkat çekmektedir. İddia olarak sunulan haberlerde, habere ilişkin yorum getirilmemektedir. Kınayıcı bir üslupla sunulan haberlerin ise çoğunlukla cinsel şiddet içerikli haberler olması dikkat çekicidir. Medyanın, yazılı basında yer alan okuldaki şiddet haberlerinin tarafsız bir biçimde olayı gündeme getirmek gibi bir hedefi olmalıdır. Aksi takdirde bu tür haberlerin gazetelerde ya da İnternet sayfalarında anlatılmasının yarardan çok zararı, toplumsal kaygıyı artırıcı yansıması olabilir. Ayrıca, çocuklara yönelik şiddet ve istismar haberlerinin veriliş şekli, haberin detayları, başka sapkın davranış ve eylemleri sıradanlaştırma, kolaylaştırma ve olabilir kılma gibi durumlara da yol açabileceği için, yeni olaylara model olabilecek durumlardan özellikle kaçınılması medyanın toplumsal bir sorumluluk görevidir.

Tablo 4'te gazetelerde yer alan haberlerin şiddet türlerine göre dağılımı yer almaktadır.

Tablo 4

Gazetelerde Yer Alan Haberlerin Şiddet Türlerine Göre Dă̆ılımı

\begin{tabular}{lccccc}
\hline Şiddet Türü & Hürriyet & Zaman & Sabah & Cumhuriyet & Toplam \\
\hline Fiziksel Şiddet & 50 & 21 & 7 & 6 & 84 \\
Psikolojik Şiddet & 16 & 7 & 7 & 4 & 34 \\
Cinsel Şiddet & 10 & 3 & 3 & 4 & 20 \\
Kurumsal Şiddet & 4 & 3 & 2 & 2 & 11 \\
Toplam & 80 & 34 & 19 & 16 & 149 \\
\hline
\end{tabular}

Tablo 4 incelediğinde gazetelerde fiziksel şiddet içerikli 84 haber, psikolojik şiddet içerikli 34 haber, cinsel şiddet içerikli 20 haber, kurumsal şiddet içerikli ise 11 haber yer almaktadır. Gazetelerde yer alan fiziksel şiddet içeren habere örnek olarak 13.05.2008 tarihinde Hürriyet gazetesinde yer alan bir haber örnek olarak verilebilir. “Mersin'in Silifke İlçesi'ndeki C. İlköğretim Okulu Müdürü Y. K.'nın, ilk dersleri boş olduğu için 'mıntıka temizliği' görevi verdiği 6/A sınıfindaki 12 kı öğrenciyi temizlikten kaçtıkları gerekçesiyle büyükçe bir pergelle sıra dayağından geçirdiği iddia edildi. Pergelin metal sivri ucunun isabet ettiği kız öğrencilerin parçalanan ellerine hastanede dikiş atıldı, müdür gözaltına alındı.” 
Tablo 5'te ise gazetelerde yer alan şiddet haberlerinin kimler arasında yaşandığına ilişkin bulgular yer almaktadır. Psikolojik şiddet içeren habere örnek olarak “Balıkesir'in Burhaniye İlçesi'nde, bir ilköğretim okulu müdürünün okula katkı parası getirmeyen yaşları 7 ve 8 arasında değişen 60 öğrenciyi bodrum kattaki bir sınıfa kapatıp, psikolojik şiddet uyguladı̆̆ iddia edildi. Öğrencilerden birinin korkup altını ıslattığı, birinin de sara krizi geçirdiği belirtilirken, veliler imza toplayıp müdür hakkında kaymakamlı̆̆a şikâyette bulundu. Olayla ilgili soruşturma başlatıldı.”, cinsel şiddet içerikli habere örnek olarak 02.02.2010 tarihinde yayınlanan okul müdürüne taciz iddiasından 24 yıl talebi başlıklı haber “Adana'da 2 kız ögrencisini elle taciz ettiği iddia edilen lise müdür yardımcısı 44 yaşındaki H.Ö. hakkında açılan iki ayrı davada toplam 24 yıla kadar hapis cezası istemiyle dava açıldı.” olarak yer aldı.

Okullarda yaşanan şiddet ve taciz yaşantıları, çocukların yaşamlarını tehdit etmekte ve yaşamlarına zarar verici olmaktadır. Bu nedenle, son zamanlarda araştırmacilar okullarda ve eğitimde şiddet, duygusal taciz (mobbing) üzerinde çözüm yollarını içerecek çalışmalara ağırlık vermişlerdir (Browning, Davis \& Resta, 2000; Johnson \& Johnson, 1995; Ley, 2002; Smith, Daunic, Miller \& Robinson, 2002).

\section{Tablo 5}

Gazetelerde Yer Alan Haberlerin Şiddet Olaylarının Kimler Arasında Yaşandı̆̆ına Göre Dă̆ılımı

\begin{tabular}{lccccc}
\hline Kişiler & Hürriyet & Zaman & Sabah & Cumhuriyet & Toplam \\
\hline Öğretmen-Öğrenci & 38 & 18 & 9 & 8 & 73 \\
Öğrenci-Öğrenci & 26 & 12 & 7 & 5 & 50 \\
Yönetici- Öğrenci & 16 & 2 & 2 & 2 & 22 \\
Öğretmen-Ebeveyn & 5 & 1 & 1 & 1 & 8 \\
Öğretmen-Öğretmen & 2 & - & 1 & - & 3 \\
Öğrenci-Okul çalışanı & 2 & 1 & - & - & 3 \\
Siyasetçi-Öğretmen & 1 & - & - & - & 1 \\
Toplam & 90 & 34 & 20 & 16 & 160 \\
\hline
\end{tabular}

Gazetelerde yer alan haberlerin şiddet olaylarının kimler arasında yaşandığına göre dağ 1 lımı incelendiğinde haberlerin 73'ünün öğretmen-öğrenci arasında, 50'sinin öğrenci-öğrenci arasında, 22'sinin yönetici-öğrenci arasında, sekizinin öğretmenebeveyn arasında, üçünün öğretmen-öğrenci arasında, üçünün öğrenci-okul çalışanı arasında, birinin ise siyasetçi-öğretmen arasında yaşandığı sonucuna ulaşılmıştır. Okulda yaşanan şiddet olaylarında ağırlıklı olarak öğrencinin olduğu, dolayısıyla, öğrencinin hem şiddet uygulayıcısı, hem de şiddet kurbanı olarak olayların içinde yer aldığı görülmektedir. Yazılı basın araçlarına yansıyan şiddet olaylarına bakıldığında, okullarda yaşanan şiddet olaylarının meydana gelmesinde okulda öğrenciler arasında yaşanan sorunlar, öğretmenlerle yaşanan sorunlar, başarısızlık, kız arkadaş sorunları gibi nedenler, okuldaki şiddet davranışını gösteren unsurlar olarak, etkili olmaktadır. Tezcan (1996) çalışmasında, ülkemizde okullarda meydana gelen şiddet olaylarının önde gelen nedenlerini, kız arkadaş sorunu, katı öğretmen davranışları, medyanın etkisi, 
yoksulluk, boş zamanı değerlendirme olanaklarının yetersizliği, polis muhbirliği, nedensiz şiddet olayları ve disipline yönelik davranışlar olarak belirtmektedir. Tablo 6'da gazetelerde yer alan haberlerin okul türlerine göre dağılımı yer almaktadır.

Tablo 6

Gazetelerde Yer Alan Haberlerin Örgün Ĕ̆itim Kademelerine Göre Dă̆ılımı

\begin{tabular}{lccccc}
\hline & Hürriyet & Zaman & Sabah & Cumhuriyet & Toplam \\
\hline Okul Öncesi & 12 & 6 & 3 & 3 & 24 \\
İlköğretim & 39 & 17 & 10 & 7 & 73 \\
Ortaöğretim & 29 & 11 & 6 & 6 & 52 \\
Toplam & 80 & 34 & 19 & 16 & 149 \\
\hline
\end{tabular}

Okulda yaşanan şiddet olaylarının örgün eğitim kurumlarında hangi kademelerde yaşandığına ilişkin gazete haberleri incelendiğinde; 73 olayın ilköğretim kurumlarında, 52 olayın ortaöğretim kurumlarında ve 24 olayın ise okul öncesi eğitim kurumlarında yaşanmış olduğu görülmektedir. Bazı gazete haberlerinde kademeler belirtilirken, bazı gazete haberlerinde ise yaş grubundan hareketle kademeler saptanmıştır.

\section{Sonuç, Tartışma ve Öneriler}

Kitle iletişim araçları; bilgi, görüş ve düşüncelerin paylaşılmasını sağlayan, sosyal örgütlenmeyi güçlendiren, kamuoyu oluşturan, insanın eğitim görme gibi temel ihtiyaçlarını karşılayan, insan ilişkilerini geliştiren, yeni davranış ve tutum kalıplarını, görüş ve düşünce akımlarını yaygınlaştıran en etkin iletişim araçlarıdır.

Okullarda meydana gelen şiddet olaylarını gazetelerde yer alan haberler aracılığgyla inceleyen bu araştırmada arşiv taraması sonucu okulda şiddetle ilgili haberlerin en çok Hürriyet gazetesinde, en az ise Cumhuriyet gazetesinde yayınlandığ sonucuna ulaşılmıştır. Akbaba-Altun, Yerin-Güneri ve Erdur-Baker (2006a) tarafından yapılan "Basındaki Yansımaları ile Okulda Şiddet" başlıklı çalışmada ise en fazla haberin Zaman gazetesinde, en az haberin ise Cumhuriyet gazetesinde yayınlandığ sonucuna ulaşılmıştır. $\mathrm{Bu}$ sonuç, araştırmanın bulgularıyla kısmen paralellik göstermektedir. Hürriyet, Cumhuriyet, Sabah ve Zaman gazetelerinin 2005-2010 yıllarını kapsayan altı yıllık arşivinin taranması sonucu yıl bazında en fazla 2006 yılında okulda yaşanan şiddete ilişkin haberin yayınlandığı sonucuna ulaşılmıştır. Bu sonuca paralel olarak diğer şiddetle ilgili haberlerin de en fazla 2006 yılında yayınlandığ bulunmuştur. Milli Eğitim Bakanlığı okullarda yaşanan şiddet olayların artmasına paralel olarak 2006 yılında Özel Eğitim Rehberlik ve Danışma Hizmetleri Genel Müdürlüğü tarafından, "Eğitim Ortamlarında Şiddetin Önlenmesi ve Azaltılması Strateji ve Eylem Planı 2006-2010” hazırlamıştır. Ülkemizde 2006 yılının ilk 5 ayında okullarda çıkan olaylarda; 14 öğrencinin öldürüldüğü, 104 öğrenci ile üç öğretmenin de yaralandığı bilgisi kitle iletişim araçlarında yer almıştır (Günday, 2006). Gazetelerde yer alan haberlerin yarısından fazlasının yorumsuz olarak sunulması, kınayıcı bir dille sunulan haberlerin ise çoğunlukla cinsel şiddet içerikli haberler olması dikkat çekicidir. 
Okulda şiddete yönelik haberlerin bazı gazetelerde sıklıkla verilmesinin, okuyucuların okulların güvenli yerler olmadığına ilişkin kaygı geliştirmelerine sebep olabilir. Toplumda şiddet kavramı çoğunlukla fiziksel şiddetle örtüştürülmektedir. Yazılı basına da en çok yansıyan şiddet türüne baktığımızda bunun fiziksel şiddet olduğu, cinsel şiddet içerikli haberlerin sayı olarak az olmasının çoğunlukla toplumda bu tür konuların tabu olarak görülmesinden kaynaklı olduğu söylenebilir. Okulda yaşanan şiddet olaylarının en fazla öğretmen-öğrenci arasında yaşandığı, bunu öğrenci-öğrenci arasında yaşanan olayların takip ettiği sonucuna ulaşılmıştır. Okulda yaşanan şiddet olaylarında ağırlıklı olarak merkezde öğrencinin olduğu dolayısıyla öğrencinin hem şiddetin uygulayıcısı, hem de kurbanı olarak olayların içinde yer aldığı görülmektedir. Yazılı basın araçlarına yansıyan şiddet olaylarına bakıldığında, okullarda yaşanan şiddet olaylarının meydana gelmesinde okulda öğrenciler arasında yaşanan sorunlar, öğretmenlerle yaşanan sorunlar, başarısızlık, kız arkadaş sorunları gibi nedenler, okuldaki şiddet davranışını etkileyen unsurlar olarak, ortaya çıkmaktadır. Tezcan (1996) çalışmasında, ülkemizde okullarda meydana gelen şiddet olaylarının önde gelen nedenlerini, kız arkadaş sorunu, katı öğretmen davranışları, medyanın etkisi, yoksulluk, boş zamanı değerlendirme olanaklarının yetersizliği, polis muhbirliği, nedensiz şiddet olayları ve disipline yönelik davranışlar olarak belirtmektedir. Okullarda yaşanan şiddet ve taciz yaşantıları çocukların yaşamlarını tehdit etmekte ve yaşamlarına zarar verici olmaktadır. Bu nedenle son zamanlarda araştırmacılar; okullarda ve eğitimde şiddet, duygusal taciz (mobbing) üzerinde çözüm yollarını içerecek çalışmalara ağırlık vermişlerdir (Browning, Davis \& Resta, 2000; Johnson \& Johnson, 1995; Ley, 2002; Smith, Daunic, Miller \& Robinson, 2002).

\section{Öneriler}

- Teknolojideki sürekli ve hızlı değişime paralel olarak, medyanın yetişkine hitap ettiği kanısı, yerini çocukların da göz ardı edilmemesi gerekliliğine bırakmıştır. Bu bağlamda gazete haberlerinde kullanılan dilde daha dikkatli olunmalıdır. Okulda şiddete ilişkin olayların ve davranışların nasıl algılandıkları, bu algıların saldırganlık ve şiddet üzerinde büyük bir rol oynadığı göz önüne alınarak, daha nesnel bir dil ile haber içeriklerinin hazırlanması hususunda farklı alan uzmanlarından yardım alınabilir.

- Her türlü kötü davranış, ihmal ve istismar karşısında ayrımcılık yapmadan çocukların korunması için önleyici önlemlerin alınması, çocuk hakları anlayışının varoluş nedenidir. Çocuklar sanal dünyada yaşadıklarını okula getirebilmektedirler. Hızla gelişen dünyada siber suçlar ile ilgili çocuklara farkındalık kazandırılmalıdır.

- Bu çalışma yazılı medya ile sınırlıdır. Görsel medyanın okulda şiddete yönelik haberleri nasıl sunduğu, haberin arka planı, doğruluk derecesi, haberin verilişinde ihmal ve duyarsızlığın olup olmadığına ilişkin çalışmalar yapılabilir. Böylece medya açısından fotoğrafın bütünü ortaya konulabilir. 


\section{Kaynakça}

Akbaba-Altun, S., Yerin-Güneri, O., \& Erdur-Baker, Ö. (2006a). Basındaki yansımaları ile okulda şiddet. Eurasian Journal of Educational Research, 24, 1221.

Akbaba-Altun, S., Yerin-Güneri, O., \& Erdur-Baker, Ö. (2006b, Mart). Bilgi ve iletişim teknolojileri çocuklarl ve gençleri nasıl etkiliyor? I. Şiddet ve Okul: Okul ve Çevresinde Çocuğa Yönelik Şiddet ve Alınabilecek Tedbirler Sempozyumunda sunulmuş sözlü bildiri, İstanbul.

Astor, R. A., Benbenishty, R., Vinokur, A., \& Zeira, A. (2006). Arab and Jewish elementary school students' perceptions of fear and school violence: Understanding the influence of school context. British Journal of Educational Psychology, 76, 91-118.

Ayrancı, Ü., Köşgeroğlu, N., \& Günay, Y. (2004). Televizyonda çocukların en çok seyrettiği saatlerde gösterilen filmlerdeki şiddet düzeyi. Anadolu Psikiyatri Dergisi, 5, 33-40.

Berg, B. L. (2007). Qualitative research methods for social sciences. Boston, MA: Allyn and Bacon.

Browning L., Davis B., \& Resta V. (2000, Spring-Summer). What do you mean think before I act? Conflict resolution with choices. Journal of Research in Childhood Education, 14(2), 232-238.

DiCanio, M. (1993). Classroom violence, the encyclopedia of violence: Origins, attitudes, consequences. New York: Facts on File.

Erkılıç, T. A. (2008). Eğitimle ilgili yazılara ilişkin yerel basın üzerinde yapılan bir çözümleme. Manas Sosyal Bilimler Dergisi, 10(19), 223-234.

Furlong, M. J., \& Morrison, G. (2000). The school in school violence: Definitions and facts. Journal of Emotional \& Behavioral Disorders, 8, 71-82.

Goldstein, A. (1994). School violence (I): Aggression of toward persons and property in America's schools. The School Psychologist, (Division of School Psychology), 48(1), 6-24.

Gümüşoğlu, F. (2006). Bilgisayar oyunlarında şiddet, çocuklar ve gençler. Toplumsal Bir Sorun Olarak Şiddet Sempozyumu Bildiriler Kitabı, 149-169.

Günday, S. (2006, 29 Mayıs). 5 ayda 14 öğrenci öldürüldü. Hürriyet, http://www.hurriyet.com.tr/gundem/4492465.asp adresinden alınmıştır.

Gürel, Z. (2006). Sesli ve görüntülü yayınlarda ahlaki yozlaşma ve şiddet karşısında çocuklarımız. Bilim ve Aklın Aydınlı̆̆ında Ĕ̈itim Dergisi, 7(75), 57-61.

Hall, S. (1999). İdeolojinin yeniden keşfi: Medya çalışmalarında baskı altında tutulanın geri dönüşü. Medya, İktidar, İdeoloji. (Der. M. Küçük,). Ankara: Ark Yayınları.

Henry, S. (2000). What is school violence? An integrated definition. The Annals of the American Academy of Political and Social Science, 567, 16-30. 
Johnson, D. W., \& Johnson, R. (1995). Training elementary school stiudents to manage conflict. The Journal of Social Psychology, 135, 673-686.

Karatay, G., \& Tokur-Kesgin, M. (2006). Çocuk, televizyon ve şiddet. Toplumsal Bir Sorun Olarak Şiddet Sempozyumu Bildiriler Kitabı, 129-148.

Kartal, O. Y., \& Kıncal, R. Y. (2009). Medya okuryazarlığı eğitimi. Milli Eğitim Dergisi, 181, 318-333.

Kızmaz, Z. (2006). Okullardaki şiddet davranışlarının kaynakları üzerine kuramsal bir yaklaşım. Cumhuriyet Üniversitesi Sosyal Bilimler Dergisi, 30(1), 47-70.

Ley, C. (2002). Conflict resolution in children and adolescents. Retrieved from http://userpages. umbc. edu/ cleyl/conflict.

McQuail, D., \& Windahl, S. (1997). Kitle iletişim modelleri. Ankara: İmge Kitabevi.

Menifield, C., Rose, W. H., Homa, J., \& Cunningham, A. B. (2001). The media’s portrayal of urban and rural school violence: A preliminary analysis. Deviant Behavior: An Interdisciplinary Journal, 22, 447-464.

Özkan, A. (2006). Küreselleşme sürecinin medya ve kültür üzerindeki etkileri (Stra. Rap. No. 15). İstanbul: Türkasya Stratejik Araştırmalar Merkezi.

Palabıyıkoğlu, R. (1997). Medya ve şiddet. Kriz Dergisi, 5(2), 123-126.

Patton, M. Q. (2002). Qualitative evaluation and research methods. Newbury Park, CA: Sage Publication.

Rodgers, S., \& Thorson, E. (2001). The reporting of crime and violence in the Los Angeles Times: Is there a public health perspective?. Journal of Health Communication, 6, 169-182.

Smith S. W., Daunic A. P., Miller M. D., \& Robinson, T. R. (2002). Conflict resolution and peer mediation in middle schools: Extending the process and outcome knowledge base. Journal of Social Psychology, 142(5), 567-587.

Terzi, Ş. (2007). Okullarda yaşanan şiddeti önleyici bir yaklaşım: Kendini toparlama gücü. Aile ve Toplum Eğitim Kültür ve Araştırma Dergisi, 3(12), 73-82.

Tezcan, M. (1996). Bir şiddet ortamı olarak okul. İstanbul: Yapı Kredi Yayınları.

Toprakçı, E. (2001). Güç merkezleri açısından okulun örgütsel farklılıkları. Kuram ve Uygulamada Eğitim Yönetimi, 7(26), 282-287.

Uysal, A. (2003). Şiddet karşıtı programlı eğitimin öğrencilerin çatışma çözümleri, şiddet eğilimleri ve davranışlarına yansıması (Yayımlanmamış doktora tezi). Ege Üniversitesi, İzmir.

World Health Organization. (1996). Mental health care law: Ten basic principles. Retrieved from http://whqlibdoc.who.int/hq/1996/WHO_MNH_MND_96.9.pdf

Yıldırım, A., \& Şimşek, H. (2008). Sosyal bilimlerde nitel araştırma yöntemleri. Ankara: Seçkin Yayıncılık. 